\title{
STUDENTS' DIFFICULTIES IN MAKING INFERENCE IN READING NARRATIVE PASSAGES AT THE SOCIAL ELEVENT GRADE OF SMAN 1 CURUP
}

\author{
Nining Warnidah \\ Bambang Suwarno \\ Arono \\ English Education Post Graduate Program \\ University of Budi Utomo Malang \\ Email : niningwarnidah@gmail.com
}

\begin{abstract}
This study aimed to find out the students' difficulties in making inference in reading narrative passages in making inference in reading narrative passages. The population of this study included the eleventh graders of SMAN 1 Curup, and the students of XI SOS 4, which consisted of 34 students, became the research sample. For the instrument, the researcher used reading test which consisted of 40 questions and questionnaire which consisted of 30 items. The result showed that the students' overall difficulty in making inference in reading narrative passages belonged to "moderate" category. It was proved by the students' reading error mean score which was 47.5 . The students' highest difficulty was on inferences about the author's attitude $(5.88 \%$, or "very high").
\end{abstract}

\section{Keywords: Students' Difficulties, Making Inference, Reading Narrative Passages.}

\section{INTRODUCTION}

Reading, which is an important skill to be taught at school (Traves, 1994:81), supports much information to improve the students' prior knowledge. Even curricula in Indonesia - KTSP and Curriculum 2013 -support this skill to be taught very much.

In reading, the students' prior knowledge is really important in supporting the students' understanding in reading the text (John-Laird (1983) in Kwiatkowska (2013)). Variety of strategies to interact with the text as well as use their English knowledge is emphasized (Peregoy \& Boyle (2001) in Kopitski (2007). It means the more prior knowledge of the reading content and the language knowledge (such as grammatical structure and vocabulary) the students have, the more they understand the text.

However, understanding school texts is not an easy matter due to the fact that they tend to be academic or nonfiction (the Basic Competence and the Core Competence available in 2013 Curriculum). And not only explicit messages of the text are asked but also the implicit ones. VanLehn (1998) in Imam, et al (2014) said, "Many school texts are difficult to understand because they often omit important background information and fail to make relations among concepts in the text explicit." Moreover, Carnine \& Carnine (2004) in Imam, et al (2014) said, "Students may have 
the ability to read and know the words, identify and locate information, and recall content, but may be unable to analyze, summarize, or critique the text when asked to do so."

Inference making, which is one of the aspects that have to be considered in reading, especially when the texts ask the readers to find out the beyond information, and when it is supported by the text comprehension, is a key component to be fluent in reading (Davoudi, 2005). The more the students are able to comprehend the text, the more they can make inference. Thus, the more fluent they are in reading and the more success the reading process will be obtained.

When students are able to make inference, reading is felt to be easier, no matter how long the text is. In making inference, the students have to read between the lines (Preszler, 2006:4). They have to understand the text implicitly - finding out themeaning beyond the text.

In order to make the reading activities more amusing or entertaining, narrative text can be given to the students since it is also an important genre of text to study (Graesser, Singer, Trabasso, 1994). This kind of text has a close correspondence to everyday experiences in contextually specific situations (Britton \& Pelligrini (1990); Bruner (1986); Kintsch (1980); Nelson (1986); Schank, (1986) in Graesser, Singer, and Trabasso (1994)).

Regarding making inference in narrative texts or passages, inferences about character, motive and feeling, authors' attitude, and irony can be asked to the students as well as giving them questionnaire in order to investigate their difficulties or problems in making inference.

The eleventh graders of social class of SMAN 1 Curup, in which the class of XI SOS 4 will become the research sample, had problems regarding this skill because of their lower score compared with those from the science class and the problems or the difficulties need to be analyzed.

Therefore, the researcher is curious to conduct the research entitled, "The Analysis of the Students' Difficulties in Making Inference in Reading Narrative Passages at the Social Eleventh Grade of SMAN 1 Curup".

\section{LIMITATION OF THE PROBLEM}

This research is limited on the investigation of the social class students' difficulties in making inference in reading narrative passages. It is because inferential skill on reading comprehension is very important for the students to belong to. When the students have this skill, they will be easier to comprehend the meaning beyond the text. Moreover, narrative passages are chosen in order to avoid the students' boredom in reading English texts and that such text can amuse the students while doing the activity.

\section{RESEARCH QUESTION}

This research is conducted based on the following research question:

What are the students' difficulties in making inference in narrative passages? 


\section{PURPOSE OF THE RESEARCH}

The purpose of this research is to find out:

1) The students' difficulties in making inference in reading comprehension;

\section{SIGNIFICANCE OF THE RESEARCH}

This research is expected to give beneficial contribution in the world of teaching and learning English, not only for English teachers, but also for lecturers, students, and other researchers. For English teachers, hopefully, by knowing the students' problems it can give important information to improve their skill in teaching reading. Furthermore, it is expected that they can develop any teaching methods which are very beneficial to assist students' comprehension in reading the text.

Additionally, for students, when their English teacher improves teaching quality, the students' comprehension of reading texts will also be affected.

Moreover, for other researchers, hopefully, this research can give any important information in improving students' comprehension of reading texts, and that they can have other deep related investigations concerning students' inferential skill.

And based on UU RI No. 20 Year 2003: in order to achieve the goal of Indonesian education, to smarten the nation life, to guarantee equal opportunity of education, to improve the quality of education (UU RI No. 20 Year 2003 about National Education System), this research is also significant to meet the need of getting equal opportunity of education.

\section{OPERATIONAL DEFINITIONS}

In this research, the writer defines specific key terms in order to avoid misunderstanding. The following definitions are considered to be useful: Inference is defined as any piece of information that is implicitly stated in a text.

1. Reading comprehension is a complex skill that requires readers to combine a variety of reading strategies to interact with the text.

2. Students' difficulties in making inference are the difficulties faced by the students when they have to infer some messages or ideas in reading the texts.

\section{THE NATURE OF READING COMPREHENSION}

Reading comprehension is a complex skill since it needs readers (students) to combine many reading strategies to understand the text. All readers need to relate their English language knowledge, world of knowledge and understanding of print to understand text (Peregoy \& Boyle, 2001) in Kopitski (2007). It is the ability to draw meaning from the text. It is more complex than the word reading as it involves a broader range of cognitive processes and thus it is viewed as the "essence of reading" (Durkin (1993) in Li, (2012:1)).

In comprehending a reading text, readers should consider about literal comprehension and inferential comprehension. Both of them are very important for them to make them easier to understand the text. In literal comprehension (e.g., textbase), readers only need a relatively shallow understanding of what the text states. While in inferential comprehension, (e.g., situation model) 
readers need a deep understanding of what the text states ( $\mathrm{Li}, 2012:$ 5-6).

In other words, it is obvious that reading comprehension is the activity of understanding texts not only shallowly but also deeply. Activities of understanding reading texts need thinking process.

\section{INFERENCE}

Inference skill is very crucial in reading comprehension. When we are trying to understand the message that is not explicitly stated in the text, it means that we are trying to do the inference skill of reading. This process of inference-making is a key component of fluent reading (Davoudi, 2005:106).

Inference is one of the most widely accepted schema notions; inferences are made on the basis of the readers' prior knowledge and input (Anderson \& Pearson, 1984). During reading comprehension, readers routinely generate possible inferences to connect information for establishing coherence in understanding the text. Inferences to establish global coherence are also generated when local coherence cannot achieve the goal (Graesser, Singer, \& Tenenbaum, 1994). (Li, 2012: 5-6).

\section{TYPES OF INFERENCE}

In Li (2012: 5-6), there are two main types of inferences. One type consists of coherence inferences which connect different pieces of information from within the text, and the other type consists of elaborative inferences which connect information from the text with prior knowledge (Barnes, Denis, \& Haefele-
Kalvaitis, 1996; Cain, Oakhill, Barnes, \& Bryant, 2001; McNamara \& Magliano, 2009).

Moreover, in Preszler (2006:13) explains that the author Kylene Beers in When Kids Can't Read, What Teachers Can Do identifies 13 types of inference:

1. Recognize pronoun antecedents .

2. Use context clues to figure out the meanings of unknown words.

3. Understand the grammatical role of unknown words.

4. Recognize character tone.

5. Identify the beliefs, personalities, and motivations of characters.

6. Understand character relationships.

7. Provide setting details.

8. Provide explanations for events and ideas in the text.

9. Offer details or their own explanations of events in the text.

10. Understand the author's point of view.

11. Recognize the author's bias.

12. Relate the text to events in their own lives.

13. Construct conclusions based from the facts in the text.

The following is the example of making inference by a skilled reader taken in Preszler (2006: 13): 


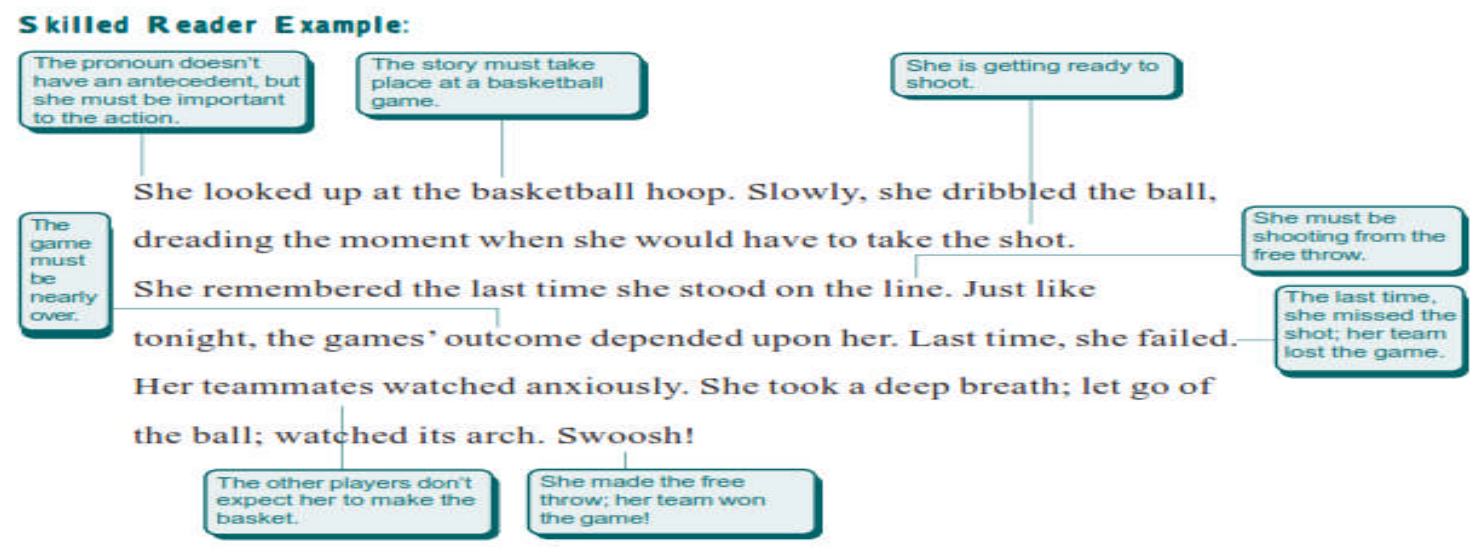

Furthermore, according to Graesser, Singer, and Trabasso (1994: 375), inference is broken down into 13 classes. They are:

1. Referential

2. Case structure role assignment

3. Causal Antecedent

4. Superordinate goal

5. Thematic

6. Character emotional reaction

7. Causal consequence

8. Instantiation of noun category

9. Instrument

10. Subordinate goal-action

11. State

12. Emotion of reader

13. Author's intent

Neil, et. al (1977) explain that there are four types of inference, namely 1 ) inference about character and actions (inferring the character of a person in the text based on the things the characters do; When the authors do not tell any actions that the characters do, then it is all up to the readers to make the inference.

Then, Niles et al (1977) explain that the readers must consider everything the author tells in the text. However, the readers must be sure not to read things into the person's behavior that the author did not intend); 2) inference about motives and feelings (It explains understanding a character's feelings and motives - the reason for his or her actions - and helps to explain the character's behavior; 3) inference about writer's attitude or tone or careful choice of words (Writers often will express attitudes or feelings about their subjects); and 4) inference about irony (There are two types of irony - situational irony (the things explained in the text is opposite of the readers' expectation and verbal irony (someone who says something but means exactly the positive); 5) and inference about point of view (often refers to who is telling the story).

In this research, the types of inference that become indicators will be that proposed by Niles et.al (1977). It is because these indicators lead to the type inference questions.

\section{INFERENCE QUESTIONS}

In reading, there are inference questions that can be identified. The question usually will have a word or phrase like "infer," "imply," or "suggests" (Rocci, 2014). The 
following questions are usually used in inference reading:

1. "This passage most likely appeared as part of ..."

2. "The author would probably agree (or disagree) with which of the following statements?"

3. "This article most likely appeared in . .."

4. "The author implies that the best control for unlicensed handguns would be ..."

5. "Which of the following might the author cite as an example of ... as it is described in the passage?"

6. “Given the author's position on ... what stand would the author probably take on the issue of ...?"

Furthermore, Kerr (2013) posted about 7 types of reading comprehension questions. And among them, there are three kinds of inference questions. They are:

\section{Inference}

Inference questions require the readers to understand what is implied by but not necessarily stated in the passage. The correct answer may rely on subtle phrases from the passage and be hard to find/less obvious than Specific questions.

- "The passage uses to imply that

- "Which of the following cannot be inferred from the passage?"

- "What does the author mean by ?'”

- "What can be inferred when the author states ?"
- The sentence, ‘___ , implies that"

2. Application

This is a slightly more specific type of inference question, where the readers are asking to choose an answer which mimics a process or exemplifies a situation described in the passage.

- Which of the following could be used to replace___ ?

- "A _ _ as conceptualized in the passage, can best be described as___ "

- "Which of the following best illustrates the situation

3. Tone

This question type is also a specific type of inference, requiring the readers to infer the author's point of view and position on certain statements.

- "The author of the passage is most likely to agree with ___?"

- "Which of the following views does the author most likely support_?"

Furthermore, these are types of questions according to Fritschmann, Schumaker, \& Deshler (2007):

1. Factual questions

2. Think and seek questions

- big picture questions (what is the author's purpose?; what is the main idea?; what is the theme?; what is the overall idea here?)

- predicting questions (what do you think will happen next?; where do you think he will go?; what will she do next?; who do you think they will find? when will they find him?; what does the future hold for her?) 
- clarifying questions (what does this word ... mean?; what does this part mean? who can make sense of it?; what caused him to do this?; what happened that made her do this?; why do you think she chose to act this way?; how would you compare (or contrast) what's happening here with what happened earlier?; how would you compare (or contrast) what she just did with what ... did?; what do you think he is feeling?; what do you suppose she was thinking when she did that?)

In this research, the researcher would like to use the types of inference questions proposed by Kerr (2013) and Rocci (2014).

\section{INFERENCE ACTIVITIES}

The followings are activities of inference suggested by Kopitski (2007): Questionanswer relationship skilled readers comprehend by asking question before, during and after reading. Question-answer relationship (QAR) is a strategy created by Taffy Raphael that can help students approach the task of reading texts and answering questions.

\section{The KIS Strategy}

KIS stand for: Key Words, Inter, Support. This Mnemonic strategy helps students remember the three steps in making and supporting inferences. First, students need to underline key words and facts from the text. Next, the readers make inferences using the key words or facts to answer the question. Lastly, the reader's list background knowledge used to support their answers.

\section{It Says I Say}

Inferring requires readers to combine information from the text with their prior knowledge. It says-I say is a visual for students to use to organize their thoughts. The reader needs to show what the text states, what scheme they have in their mind and what conclusions they can make based on that information.

\section{Marking texts}

In order for reading strategies to be useful, students need to monitor them. This requires readers to focus while reading. Marking texts is one way that can help students stay focused on their reading.

Moreover, according to Fritschmann, Schumaker, \& Deshler (2007), there are steps for the inference strategy can be applied in the classroom. They are as follows:

1. Interact with the questions and the passage.

2. Note what you know.

3. Find the clues.

4. Explore any supporting details.

5. Return to the question.

\section{REVIEW OF RELATED STDIES}

There have been many studies investigating about inference. Here are a few of them:

The first was the study conducted by Cain, et al (2001). In this study they investigated the relation between young children's comprehension skill and inference making ability by using a procedure that controlled individual differences in general knowledge (Barnes \& Dennis, 1998; Barnes, Dennis, \& HaefeleKalvaitis, 1996). A multi episode story was 
read to the children and their ability to make two types of inference was assessed: coherence inferences, which were essential for adequate comprehension of the text, and elaborative inferences, which enhanced the text representation but which were not crucial to understanding. There was a strong relation between comprehension skill and inference-making ability even when knowledge was equally available to all participants. Subsidiary analyses of the source of inference failures revealed different underlying sources of difficulty for good and poor comprehenders.

The second study was by Baretta, et al (2009). In this study, the process of inference making by native speakers of English while reading two different types of text was investigated using electroencephalography (EEG). The subjects read narrative and expository paragraphs, and judged the plausibility of the final sentence of each four-sentence long paragraph by reference to the previous information. The analysis of data focused on the N400 component and on accuracy of behavioral responses. N400 amplitudes revealed that exposition was more demanding than narration in terms of semantic processing, whereas the behavioral data showed that subjects were more prone to generate inferences when reading exposition. Overall, this study suggests that these two types of text are processed differently by the brain, as revealed by the changes in the N400 component across the last sentences of the paragraphs.
The third was the study conducted by Attaprechakul (2013). This study aimed to explore inference strategies necessary to successfully read journal articles. In this study, there were eighty eight graduate students read a set of texts on education and economic growth and answered comprehension questions. Twenty-four of these participants also volunteered for an indepth interview. It was found that the students usually relied on their bottom-up processing. They skipped difficult parts, especially technical information and graphic illustrations. They sought help from friends to enhance their understanding. Overall, they were successful at interpreting the thesis statement, the gist of the section, the meaning of the tested words and clause. However, they were less able to infer the underlying argument, the tone of the article, and the attitudes of others toward the research findings. A substantial number of students also failed to utilize information from section headings and the organization of research articles to guide their reading tasks.

The fourth study was conducted by Arianti (2013). This research investigated the significance and effectiveness of teaching narrative text inference by using DRTA strategy. It was a pre experimental design with one group pre-test post-test design. The subject was Grade XI IPA 1, numbering thirty four students. The data were collected by giving 30 multiple choice items to the 34 students and were analyzed by using t-test and effect size formula. The results indicated that teaching by using DRTA strategy increases students' ability 
of narrative text-based inference-making significantly. Its effectiveness is high.

The fifth study was conducted by Azizmohammadi (2013). In this study, two fairly homogeneous groups of EFL learners were selected $(\mathrm{N}=46)$ in Arak University. They were studying in English translation. After taking a reading comprehension test to ensure that their reading comprehension differences were not significant, they were randomly assigned to attend a short-story course in two different sections, one serving as the experimental and the other as the control group, both studying the same short stories, and both being taught by the researcher as their instructor of the course. By using T-test and ANOVA, the researchers found that in recall test which administered two weeks later, the learners who could draw inferences significantly outperformed the other learners in reading comprehension test.

The sixth study was by Imam, et al (2014). The research work was carried out among randomly selected 666 first year student-respondents from 18 identified public and private high schools in the Division of Cotabato City, Central Mindanao, Philippines. The six elements of reading comprehension skills, i.e., understanding vocabulary in context, identifying main idea, noting details, making inference, predicting outcomes, and drawing conclusion, and students' performance in science from the two school types were described and correlated. A competency-based 50-item multiple choice achievement test for each of the reading comprehension and science learning areas was utilised as the research instrument. The test was developed based on the prescribed Table of Specifications (TOS) and aligned with learning competencies formulated under the Restructured Basic Education Curriculum (RBEC) of the Department of Education (DepEd). The study results showed that the overall students' performance in reading comprehension and science was indexed at low mastery level. Generally, four out of six reading skills such as understanding vocabulary in context, noting details, predicting outcome, and making inference made up the overall reading skills that positively correlated with science performance of students although the strength of relationship was considered weak.

The seventh study was conducted by Cain (2015). This study, the second aimed to explore inference strategies necessary to successfully read journal articles. In this study, there were eighty eight graduate students read a set of texts on education and economic growth and answered comprehension questions. This was a study of 4- to 6-year-olds that had two aims. The first aim was to determine how lower-level comprehension skills (receptive vocabulary and grammar) and verbal memory support early higher-level comprehension skills (inference and literal story comprehension). The second aim was to establish the predictive power of these skills on subsequent reading comprehension. Eightytwo children completed assessments of nonverbal ability, receptive vocabulary and grammar, verbal short-term memory, and inferential and literal comprehension of a 
picture book narrative. Vocabulary was a unique predictor of concurrent narrative comprehension. Longitudinally, inference skills, literal comprehension and grammar made independent contributions to reading comprehension one year later. The influence of vocabulary on reading comprehension was mediated through both inference and literal comprehension. The results showed that inference skills are critical to the construction of text representations in the earliest stages of reading comprehension development.

The studies above showed inference making and inference strategies in comprehending reading texts. However, the study of students' difficulties and the students' perception of difficulties in making inference in reading narrative passages has not been found yet. Therefore, the researcher is interested to conduct such research regarding students' difficulties in making inference so that it will be very beneficial for teachers when teaching reading comprehension.

\section{METHODOLOGY}

This is a descriptive quantitative research because it tried to describe the difficulties faced by the students at the eleventh grade of SMAN 1 Curup, Bengkulu. It used quantifiable data from participants and analyzed the data by using statistics and the variables were described without regard to causal or other hypotheses.

\section{POPULATION AND SAMPLE}

The population of this research was the social eleventh grade students of SMAN 1
Curup which consisted of 145 students. In determining the sample, the researcher used cluster random sampling technique. It means that every social class has chance to be the sample due to the students' same knowledge and ability in critical reading. Therefore, the researcher would take class XI SOS 4 which consisted of 34 students to be the research sample.

\section{INSTRUMENTATION}

The instruments used in this research are a 40 item reading test and a 30 item questionnaire which used Likert scale. The instruments had been tried out before being given to the students. And all of them used the types or indicators of inferences proposed by Neil, et al (1977).

\section{VALIDITY AND RELIABILITY OF INSTRUMENT}

\section{Validity and Reliability of the Reading Test}

\subsection{Validity}

In order to measure the reading test validity, item characteristics that include the Facility Value (FV) and Discrimination Index are used. For Facility Value, an average of 0.3 -0.7 percent might be desirable. While for discrimination index, an index of $\geq 0.3$ is desirable.

\subsection{Reliability}

The ideal reliability of the coefficient is 1 (one). To find out the instrument reliability, KR21 formula is used (Yusuf, 2014).

\section{TECHNIQUE OF DATA COLLECTION}

In collecting the data, the researcher firstly administered a narrative reading test which consisted of 50 questions. To see the validity and reliability of the test, the 50 
questions of reading test would be tried out before it was given to the students. And the students should choose the best answer of the multiple answer choices of each question within 90 minutes.

\section{TECHNIQUE OF DATA ANALYSIS}

Data analysis deals with data on student's difficulties in which the researcher tried to find the students' raw error by counting the number of errors that are made by the students when they did the reading test. The raw error figures are then converted to adjusted error figure.

\section{RESULT AND DISCUSSION}

Result of Try Out

Based on the try out result, among 50 reading test items, there were 40 valid items to be accepted as the research instrument. The reliability result was 0.89 , and it showed that the instrument had very high reliability.

\section{RESULT AND DISCUSSION OF DATA ANALYSIS}

The reading test result (table 1) showed that the students' mean score was 47.5. It indicated that the students' difficulties in making inference were "moderate". And from table 2 , it was obvious that the students had the highest difficulties on the indicator of inferences about "the author's attitude" that was proved by the highest percentage of difficulties, $5.88 \%$ (very high).

Table 1: The Overall Average of Students' Difficulties in Making Inference and per Indicator

\begin{tabular}{|l|c|c|}
\hline \multicolumn{1}{|c|}{ Types of Inference } & Average & Category \\
\hline Inference about Character & 17.35 & Moderate \\
\hline Inference about Motive and Feeling & 5.88 & Moderate \\
\hline Inference about the Author's Attitude & & Moderate \\
\hline Inference about Irony & 14.71 & Moderate \\
\hline & & \\
\hline
\end{tabular}


Table 2: The Percentage of the Students' Difficulties in Making Inference for Each Indicator and Overall

\begin{tabular}{|c|c|c|c|c|c|c|c|c|c|c|c|c|}
\hline \multirow[t]{2}{*}{ INDICATOR } & \multicolumn{2}{|c|}{$\begin{array}{l}\text { VERY } \\
\text { HIGH }\end{array}$} & \multicolumn{2}{|c|}{ HIGH } & \multicolumn{2}{|c|}{ MODERATE } & \multicolumn{2}{|c|}{ LOW } & \multicolumn{2}{|c|}{$\begin{array}{l}\text { VERY } \\
\text { LOW }\end{array}$} & \multicolumn{2}{|c|}{ TOTAL } \\
\hline & $\mathbf{f}$ & $\%$ & $\mathbf{f}$ & $\%$ & $\mathbf{f}$ & $\%$ & $\mathbf{f}$ & $\%$ & $\mathbf{f}$ & $\%$ & $\mathbf{N}$ & $\%$ \\
\hline I.C & 0 & 0 & 6 & 17.65 & 10 & 29.41 & 17 & 50 & 1 & 2.94 & 34 & 100 \\
\hline I.MF & 0 & 0 & 7 & 20.59 & 10 & 29.41 & 6 & 17.64 & 11 & 32.35 & 34 & 100 \\
\hline I.AA & 2 & 5.88 & 11 & 32.35 & 14 & 41.18 & 6 & 17.65 & 1 & 2.94 & 34 & 100 \\
\hline I.I & 0 & 0 & 8 & 23.53 & 9 & 26.47 & 16 & 47.06 & 1 & 2.94 & 34 & 100 \\
\hline OVERALL & 0 & 0 & 8 & 23.52 & 11 & 32.35 & 14 & 41.18 & 1 & 2.94 & 34 & 100 \\
\hline
\end{tabular}

Note:

I.C = Inferences about Character

I.MF = Inferences about Motive and Feeling

I.AA $=$ Inferences about the Authors' Attitude

I.I = Inferences about Irony

\section{DISCUSSION}

As what had been explained in the previous chapter, inference is one of reading strategies the students should have in order to be a good reader. Gibson (2009) explains, "Inferring is reading between the lines, and for many students, it is a difficult strategy to master. Inferring involves drawing a conclusion or making an interpretation that is not explicitly stated in the text." Furthermore, Harvey, S. \& Goudvis, A., 2007, p. 18 in Gibson (2009) explain,

"Students infer when they take what they already know, their background knowledge, and merge it with clues in the text to draw a conclusion, surface a theme, predict an outcome, arrive at a big idea, and so forth. If readers don't infer, they will not grasp the deeper essence of texts they read."
Being an active or good reader is not easy since it needs two elements of reading - external and internal. Having the external one element only is not enough. External element which needs students as readers to decode words needs to be supported by the internal element which is the actual understanding of the text that allows students to comprehend the content. In other words, in order to be engaged with the text and truly think about what they are reading, decoding words only is not enough. Students who can decode words do not guarantee that they can understand what decoded words and sentences mean (Zimmerman and Hutchins (2003) in Gibson (2009: p. 14)).

Making inference which is one of the strategies to reach the latter element of reading cannot be denied in order to let the students to actively read the narrative texts. 
Their difficulties in making inference can influence them in understanding the text.

Compared with other researches, this research and the others, as they had been mentioned above, were similar due to their inference making investigation. However, they were different in terms of subjects, the texts given to the subject of their research, and theme or topic of investigation.

Compared with the first study conducted by Cain, et al (2001), they investigated the relation between young children's comprehension skill and inference making ability by using a procedure that controlled individual differences in general knowledge. In here, a multi episode story was read to the children and their ability to make two types of inference - coherence inferences and elaborative inferences was assessed. Additionally, the study or research conducted by Baretta, et al (2009) was also quite different from this research. In their study, the process of inference making by native speakers of English while reading two different types of text was investigated using electroencephalography (EEG).

The subjects read narrative and expository paragraphs, and judged the plausibility of the final sentence of each four-sentence long paragraph by reference to the previous information. Furthermore, the third study conducted by Attaprechakul (2013) explored inference strategies necessary to successfully read journal articles. Moreover, the fourth study conducted by Arianti (2013) investigated the significance and effectiveness of teaching narrative text inference by using
DRTA strategy. In addition, the fifth study by Azizmohammadi (2013) asked two fairly homogeneous groups of EFL learners in Arak University, who were studying English translation, to attend a short-story course in two different sections, one serving as the experimental and the other as the control group, both studying the same short stories, and both being taught by the researcher as their instructor of the course. Then, the sixth study by Imam, et al (2014) was also different from this research. Imam, et al (2014) tried to describe and correlate the six elements of reading comprehension skills, i.e., understanding vocabulary in context, identifying main idea, noting details, making inference, predicting outcomes, and drawing conclusion, and students' performance in science from the two school types. And the last study in this research, as it had been mentioned in the previous chapter was by Cain (2015). It explored inference strategies necessary to successfully read journal articles.

Since this research analyzed the students' difficulties in making inference in reading narrative passages, this research was very beneficial to English teachers. By knowing their difficulties in making inference in reading narrative passages, the teachers then can follow up the problems by giving the students some treatments or by improving their teaching quality so that the students' difficulties in making inference in reading narrative texts can be recovered.

However, since this research was only limited on narrative passages, there must have been different scores if the same passages were applied on other classes. It 
was because the scores (the students' difficulties, the students' perception of difficulties, and the relationship between the students' difficulties and the students' perception of difficulties) obtained could not be generalized. Also, it means that when other kinds of passages were applied on the same or different students the result might have been different. Moreover, this research was only limited in terms of location. It took place in Curup. Even though it was categorized into regency, it was still in the town. It means that, the results must have been different too when being applied in villages there.

Seeing the results of this research, actually this was not a bad news to the English teachers. It did not reflect the teachers' failure in teaching English to the students due to the "moderate" level of the students' difficulties in making inference. Moderate level here means that actually the students did not have fatal difficulties in making inference in reading narrative passages. Since the students' biggest problem was on making inferences about the authors' Attitude, the teacher then can give more reading exercises related to the problem so that the problem can be solved then. Further, the teachers can improve their teaching quality when teaching the students inferential skill by finding out interesting teaching and or learning technique to figure out the students' problems in reading comprehension especially reading narrative passages. The teacher should think of ways so that reading can become enjoyable and fun for the students so that their difficulties in understanding reading text can be reduced.

Meanwhile, for students, it is better for them to read more narrative passages especially regarding making inferences about the authors' attitude so that when they meet such type of passages in the future, they did not have the same difficulties anymore.

And lastly, it is expected for other researchers in the future that this research is able to give any important information in improving students' comprehension of reading texts. And hopefully the next researcher can have other deep related investigations concerning students' inferential skill, for example by doing an experiment regarding improving the students' reading ability by using inferential skill or other reading strategies or the combination of the reading strategies so that the students can be active readers, by investigating why the students are difficult in making inference in reading narrative passages, or by using a technique of teaching that can be applied in any reading classes to improve students ability in making inference in reading comprehension. Furthermore, since this research was conducted in Curup (the town in Curup regency), it is better for the next researcher to conduct different investigation in villages of that regency or other regencies in Bengkulu due to the fact that there must be different score when the research was applied on different locations. Finally, other investigations related to inference making with different kinds of 
passages except for narrative ones are also expected.

\section{CONCLUSION AND SUGGESTION}

\section{Conclusion}

Based on the results in the previous chapter, it can be concluded that the students had problems or difficulties and perception of difficulties in inferences about the author's attitude.

Suggestions

Based on the conclusion above, the researcher suggests the current or the future researcher to conduct an inquiry on 1) factors that can influence the students' difficulties in making inference in reading narrative passages or why students are difficult in making inference in reading narrative passages; 2) improving the students reading comprehension through making inference or other reading strategies or the combination of the reading strategies so that the students can be active readers; 3) using a technique of teaching that can be applied in any reading classes to improve students ability in making inference in reading comprehension; 4) inference making in different locations especially in villages in Curup and with different kinds of passages except for narrative ones.

For English teachers, reading between the lines is not an easy thing to do by the students. It is better for the teacher to find out interesting teaching and or learning technique to figure out the students' problems in reading comprehension especially reading narrative passages. The teacher should think of ways so that reading can become enjoyable and fun for the students so that their difficulties in understanding reading text can be reduced. And more exercises regarding inference making should be given to the students as we know that practice makes perfect. Moreover, it is better for the teacher to teach reading tricks or tactics so that the students become familiar with even longer texts.

\section{REFERENCES}

Arianti, N. (2013). Teaching narrative text inference by using directed reading thinking activity (DRTA) strategy. Pontianak: Tanjung Pura University..

Arikunto, S. (2006). Prosedur penelitian: Suatu Pendekatan Praktik Edisi VI. Jakarta: PT. Rineka Cipta.

Attaprechakul, D. (2013). Inference strategies to improve reading comprehension of challenging texts. English Language Teaching, 6(3), 82-91.

Azizmohammadi, F. (2013). Investigating the effect of drawing inferences in EFL leamers reading comprehension ability by using recall of short stories.International Journal of Language and Linguistics, 1(4), 155-159.

Baretta, L., Tomitch, L.L.B., MacNair, N., Lim, V.K., \& Waldie, E. (2009). Inferencemaking while reading narrative and expository texts. Psychology \&Neuroscience, 2(2), 137-145.

Cain, K. (2015). The relations between lower- and higher-level comprehension skills and their role in prediction of early reading comprehension. Journal of Educational Psychology, 107(2), 321331.

Cain, K., Oakhill, J.V., Barnes, M.A., \& Bryant, P.E. (2001). Comprehension skill, inference making ability, and their relation to knowledge. Memory and Cognition, 29(6), 850-895. 
Clark, C., Osbome, S., \& Akerman, R. (2008). Young people's self-perceptions as readers (An investigation including family, peer, and school influences). London: National Literacy Trust.

Creswell, J W. (2007). Qualitative Inquiry \& Research Design (Choosing Among Five Approaches). Califomia: Sage Publications, Inc.

Creswell, J. W. (2008). Educational Research (Planning, Conducting, and Evaluating Quantitative and Qualitative Research) (3 ${ }^{\text {Id }}$ ed.).The United States of America:Pearson.

Davoudi, M. (2005). Inference Generation Skill and Text Comprehension. The Reading Matrix, 5 (1), $106,108$.

Filiatrault, A. (2008). Students' perception of themselves as readers. Retrieved from http://reflectivepractitioner.pbworks.com/f/Filiatra ult+Capstone.pdf

Gay, L. R. (1987). Educational research (competencies for analysis and application $\left(3^{\text {rd }}\right.$ ed.).Colombus, Toronto, London, Melboume: Memil Publishing Company.

Gibson, K. D. (2009). Teachers' perceptions of strategy based reading instruction for reading comprehension. San Rafael, CA: School of Education Dominican University of Califomia. Retrieved from http://files.eric.ed.gov/fulltext/ ED505543.pdf

Graeser, A.C., Singer, M., \& Trabasso, T. (1994). Constructing inferences during narrative text comprehension. Psychological Review. 101 (3), 371-395.

Grimes, D. A., \& Schulz, K. F. (2002). Descriptive studies: what they can and cannot do (epidemilogy series). The Lancet, (359), 145.

Heaton, J. B. (1998). Writing English language tests (new ed). The United States of America: Longman.
Hill, Robin. (1998). What sample size is "enough" in intemet survey research?. AECT, 6 (3-4), 3-5.

Imam, O. A., Mastura, M. A., Jamil, H., \& Ismail, Z (2014). Reading comprehension skills and performance in science among high school students.

in philippines. Asia Pasific Journal of Educators and Education, 29(81-94), 83-84.

Javed, M., Eng, L. S., Mohamed, A. R. (2015). Developing reading comprehension modules to facilitate reading comprehension among malaysian secondary school ESL students. International Journal of Instruction, 8 (2), 139154.

Kopitski, M. (2007). Exploring the teaching of inference skills. Minnesota: Hamline University. Retrieved from http://www.google.com.

White, K. B. (2012). Understanding reading comprehension performance in high school students. Canada: Queen's University. Retrieved from https://qspace.library. queensu.ca/ bitstream /1974/7395/1/KwiatkowskaWhite_Bozena_201 208 Ph.D.pdf

Li, M. (2012). Understanding reading comprehension in english immersion students in china. Canada: Queen's University.

Neil, et al. (1977). Reading Tactic. International Reading Association.

Pierloni, C. (2012). Student perception of their own reading achievement and the motivational factors which affect this achievement. Fisher Digital Publications: St.John Fisher College. Retrieved from

http://fisherpub.sjfc.edu/cgi/viewcontent.cgi?articl $\mathrm{e}=1217 \&$ \&ontext=education ETD masters.

Preszler, J. (2006). On target: Strategies to make readers make meaning through inferences (grade 4 - 12). E S A Regions 6 \& 7. Retrieved from http://www.rainbowschools.ca/virtual library/tea 
cher_resources/support/Making-Inferences-

booklet-On-Target.pdf

Rocci, K. (2014). Inferences questions in GRE reading comprehension. Retrieved from http://magoosh. $\underline{\mathrm{com}}$

Silva, M., \& Cain., K. (2015). The relations between lower-and higher-level comprehension skills and their role in prediction of early reading comprehension (higher level language and reading comprehension). Joumal of Education Psychology, 107 (2), 321-331.

Sugiyono. (2013). Metode penelitian kuantitatif, kualitatif dan $R$ \& $D$. Bandung: Penerbit Alfabeta.
Traves, P. (1994). Teaching English. In Brindley, S (Ed.), New York: Routledge.

Virtue, S., Haberman, J., Clancy, Z, Parnish, T., \& Beeman, MJ. (2006). Neural activity of inferences during story comprehension (Research Report). Elsevier Brain Research, 104-114.

Yusuf, A. Muri. (2014). Metode penelitian kuantitatif, kualitatif \& penelitian gabungan. Jakarta, Indonesia: Prenadamedia Group. http://www.merriam-webster.com / dictionary / perception. 